\title{
The role of GABA neurotransmitter in the human central nervous system, physiology, and pathophysiology
}

\author{
Lenin D. Ochoa-de la Paz ${ }^{1,2 *}$, Rosario Gulias-Cañizo ${ }^{3}$,Estela D’Abril Ruíz-Leyja², Hugo Sánchez-Castillo4, \\ and Jorge Parodi ${ }^{5}$ \\ ${ }^{1}$ Departamento de Bioquímica, Laboratorio de Neurobiología Molecular y Celular de la Glía, School of Medicine, Universidad Nacional Autónoma de \\ México, Mexico City; ${ }^{2}$ Departamento de Investigación, Asociación para Evitar la Ceguera en México I.A.P., Hospital Dr. Luis Sánchez Bulnes, Mexico \\ City; ${ }^{3}$ Universidad Anáhuac México, Huixquilucan, State of Mexico; ${ }^{4}$ Laboratorio de Neuropsicofarmacología y Estimación Temporal, Faculty of \\ Psychology, Universidad Nacional Autónoma de México, Mexico City. Mexico; ${ }^{5}$ School of Sciences, Universidad Mayor, sede Temuco, Temuco, Chile
}

\begin{abstract}
GABA is the main inhibitory neurotransmitter of the central nervous system (CNS) and one of the most abundant neurotransmitters in mammals is distributed in most areas of the brain and participates in $40 \%$ of the inhibitory synapses of adult vertebrates. It is produced in the CNS, through the decarboxylation of glutamic acid, catalyzed by glutamic acid decarboxylase (GAD). $G A B A$ exerts its inhibitory effect through two types of specific receptors, $G A B A_{A}$ (ionotropic) and $G A B A_{B}$ (metabotropic), which show different pharmacological, structural, and molecular differences. Even though GABA plays a key role in the physiology of the CNS modulating different processes, also is involved in some pathologies, furthermore, is a target for several therapeutics drugs. For instance, GABA has important involvement in sleep cycle regulation, and for decades benzodiazepines and gaboxadol have been prescribed for the treatment of insomnia. In epilepsy disease, the pharmacological and gene expression studies suggest a role in the prevention of seizures by blocking the regulation of GABA $A_{A}$ receptors with specific antagonists. In depression and anxiety, studies indicate changes in the regulation of the genes which encoding GABA receptors. In the same way, GABA receptors have been associated with alcoholism and premenstrual syndrome. In conclusion, experimental evidence suggests, that the same subtype of GABA receptors showed a different pattern of cellular population and subcellular expression in different areas of the brain, modulating the excitability, and neuronal synchronization in different affection pathologies and conditions in humans.
\end{abstract}

Key words: Human. GABA. GABA receptors. Central nervous system. Physiology. Pathophysiology.

\section{El papel del neurotransmisor GABA en el sistema nervioso central humano, fisiología, y fisiopatología}

\section{Resumen}

El GABA es el principal neurotransmisor inhibitorio en el sistema nervioso central (SNC) y uno de los más abundantes en mamiferos; se distribuye en diferentes áreas del cerebro y participa en el $40 \%$ de las sinápsis de vertebrados adultos. Su síntesis se realiza en el SNC a través de la descarboxilación del ácido glutámico por acción de la descarboxilasa del ácido glutámico (GAD). El efecto ihibitorio de GABA se ejerce a través de dos tipos de receptores específicos: $G A B A_{A}$ (ionotrópi-

\section{Correspondence:}

*Lenin Ochoa-de la Paz

E-mail: lochoa@unam.mx
Available online: 17-03-2021

Date of reception: 27-05-2020

Date of acceptance: 14-10-2020

DOI: 10.24875/RMN.20000050
Rev Mex Neuroci. 2021;22(2):67-76

www.revmexneurociencia.com

2604-6180/ @ 2020 Academia Mexicana de Neurología A.C. Published by Permanyer. This is an open access article under the CC BY-NC-ND license (http://creativecommons.org/licenses/by-nc-nd/4.0/). 
cos) y $\mathrm{GABA}_{B}$ (metabotrópicos), los cuales presentan características farmacológicas, estructurales y moleculares diferentes. A pesar de que GABA participa de manera importante regulando diferentes procesos en el SNC, también está involucrado en algunas patologías, por lo que sus receptores son un blanco terapéutico. Por ejemplo, GABA participa en la regulación del ciclo del sueño, y por décadas las benzodiazepinas y el gaboxadol se han prescrito para el tratamiento del insomnio. En epilepsia, estudios farmacológicos y de expresión génica sugieren una participación en la prevención de las crisis al bloquear los receptores $G A B A_{A}$ con antagonistas específicos. En el caso de la depresión y ansiedad, estudios indican cambios en la regulación de genes que codifican para los receptores a GABA. En este mismo sentido, los receptores a GABA también se han asociado al alcoholismo y al síndrome premenstrual. En conclusión, la evidencia experimental sugiere que el mismo subtipo de receptor a GABA presenta patrones diferentes en las poblaciones celulares y en su expresión subcelular en diferentes áreas del cerebro, modulando la excitabilidad y sincronización neuronal en diferentes condiciones y afecciones patológicas en humanos.

Palabras clave: Humano. GABA. Receptores GABA. CNS. Fisiología. Patofisiología.

\section{Introduction}

Amino acids ( $A A)$ are the basic units of proteins; if there is any AA deficiency, the synthesis of proteins is altered, causing a unbalance in the cellular physiology and organism. AA have different functions and are essential for the physiology of the body; for example, hormones such as insulin, growth hormone, and glucagon, are made up of AAs. It is known that some AAs regulate the in vitro and in vivo secretion of insulin in pancreatic $\beta$-cells. AAs play an important role in different processes related to gene expression, including the modulation of proteins that regulate $\mathrm{mRNA}^{1}$.

In the central nervous system (CNS), some AA are neurotransmitters and have a key role in neuronal communication, such as glutamate and glycine. In the case of GABA, despite that chemical structure, it is not considered like $A A$, because it does not conform proteins. These neurotransmitters are stored in vesicles inside the presynaptic neuron and released into the synaptic cleft by a $\mathrm{Ca}^{2+}$-dependent mechanism and in response to a depolarizing stimulus. These neurotransmitters generate excitatory or inhibitory responses through binding to their specific receptors in the post-synaptic neuron or even the same presynaptic cell. A malfunction of these neurotransmitter communication systems is associated with different neurological or psychiatric disorders. For this reason, several pharmacological therapies aim to regulate release mechanisms, receptor binding, or neurotransmitter reuptake.

In this review, we will focus on the inhibitory neurotransmitter GABA ( $\gamma$-aminobutyric acid), specifically in the participation of their receptors in different neurodegenerative disorders and the different pharmacological strategies aimed at their regulation for the treatment of these pathologies.

\section{GABA}

GABA is the main inhibitory neurotransmitter of the CNS and one of the most abundant neurotransmitters in mammals. It was first described in the early 1900s, while its presence and participation as a neurotransmitter in the mammalian CNS was determined until the 1950s. During the following two decades, many studies established its mechanism of action, as well as its inhibitory activity in the cerebral cortex ${ }^{2}$. We, currently, know that GABA is distributed in most areas of the brain and participates in $40 \%$ of the inhibitory synapses of adult vertebrates.

\section{GABA metabolism}

GABA is produced in the CNS, through the decarboxylation of glutamic acid, and catalyzed by glutamic acid decarboxylase (GAD). In general, the enzymatic activity of GAD is regulated by its expression levels and the degree of association with the cofactor pyridoxal phosphate (PLP) ${ }^{3}$. GAD has two isoforms, $G_{A D}$ and $\mathrm{GAD}_{67}$, both encoded by different genes, and different expression patterns, but with similar mechanisms regulating their function ${ }^{4,5} . G A D_{65}$ is located mainly in the synaptic terminals, where it induces vesicular GABA release in a $\mathrm{Ca}^{2+}$-dependent process. $\mathrm{GAD}_{65}$ dissociates from PLP under physiological conditions and increases its activity depending on the demands of the synaptic release of GABA ${ }^{6}$. Therefore, the main regulatory mechanism for this isoform is the association with its cofactor and not it is level of expression ${ }^{3}$.

$\mathrm{GAD}_{67}$ is expressed in the cytoplasm, it is associated with PLP under physiological conditions, and is regulated by its levels of expression. $G_{A D}$ is involved in cell metabolic activity and is responsible for most of the GABA synthesis in the brain ${ }^{3}$. However, it has been 


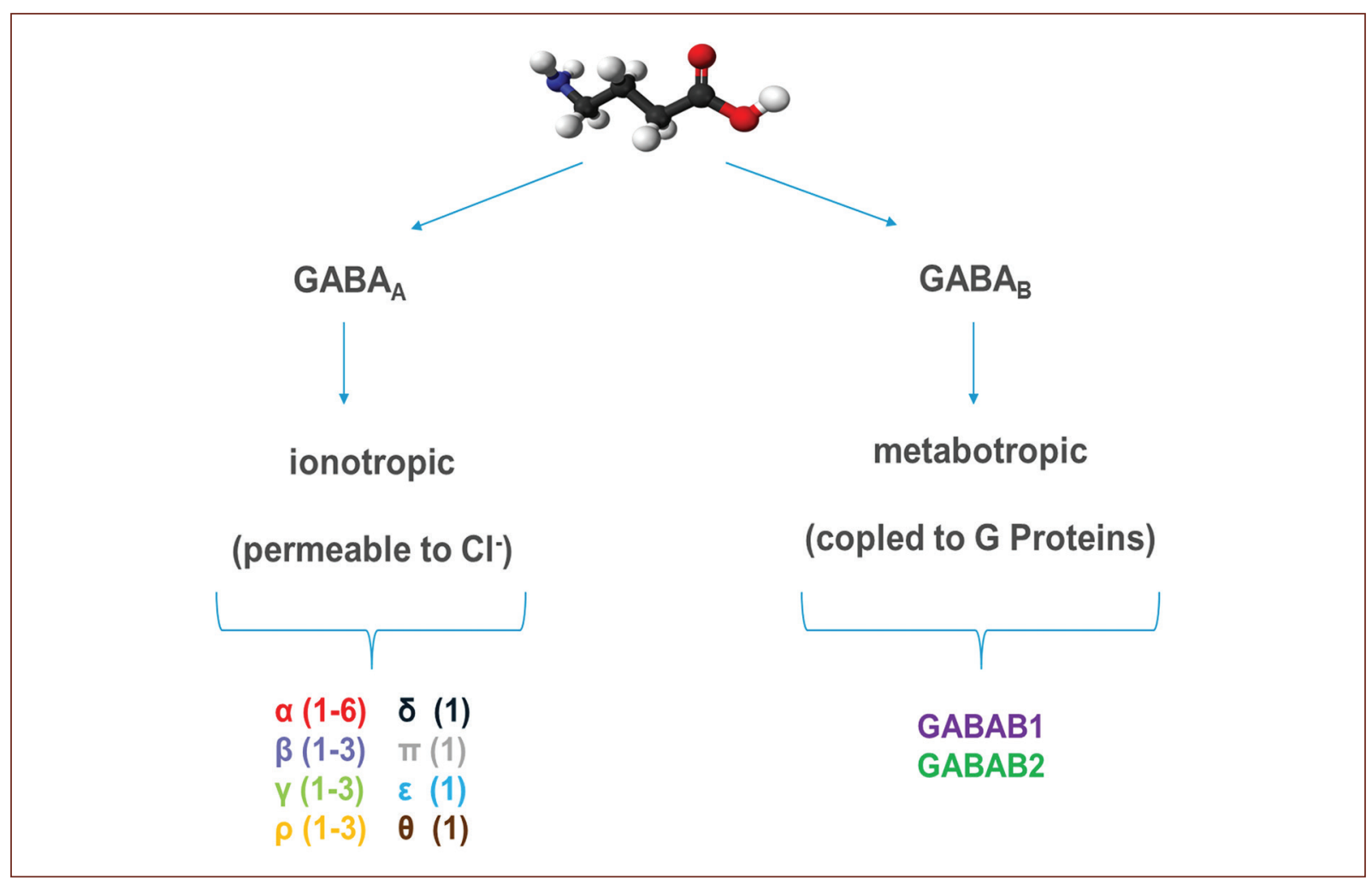

Figure 1. Representative molecular structure of GABA and GABA receptors. GABA is a full agonist of two types of receptors, named according to their mechanism of action. $\mathrm{GABA}_{\mathrm{A}}$ or ionotropic receptors, are protein channels activated by GABA and permeable to $\mathrm{Cl}$-. These receptors are conformed by different subunits, six type $\alpha$, three type $\beta$, three type $\gamma$, and one each of type $\delta, \varepsilon, \pi$ and $\theta . G A B A_{B^{\prime}}$ or metabotropic receptors, are receptors coupled to $\mathrm{G}$ proteins that modulate $\mathrm{K}^{+}$and $\mathrm{Ca}^{2+}$ channels and are conform for only two subunits. The GABA structure was from https://es.wikipedia.org/wiki/Ácido_r-aminobutírico (Last accessed on September 20, 2020).

suggested that cytoplasmic GABA can be released by a $\mathrm{Ca}^{2+}$-independent mechanism. If this is correct, then $\mathrm{GAD}_{67}$ may participate in inhibitory neurotransmission by activating extra-synaptic GABA receptors.

After GABA release into the synaptic cleft, it is reuptake by the GAT-1 and GAT-3 transporters, these systems are expressed in both neurons and glial cells. GABA catabolism is carried out through the GABA transaminase (GABA-T). GABA-T is dependent on PLP, which, in turn, requires $G A B A$ and $\alpha$-ketoglutarate as substrates, generating glutamic acid, and succinic semialdehyde (SSA) as by-products. SSA can be metabolized into $\gamma$-hydroxybutyric acid, which regulates $\mathrm{GABA}_{B}$ receptors, or can be dehydrogenated to succinate. When GABA is dehydrogenated to succinate via SSA dehydrogenase, it is incorporated into the Krebs cycle, where it participates in cellular energy metabolism. Many clinical and preclinical researches indicate the presence of GABAergic neurons in regions such as the amygdala, hippocampus, hypothalamus, prefrontal cortex, olfactory bulb, retina, and spinal cord.

\section{GABA receptors}

GABA exerts its inhibitory effect through two types of specific receptors called $G A B A_{A}$ and $G A B A_{B}$, which show different pharmacological, structural, and molecular differences (Fig. 1). GABA $A$ receptors, or ionotropic, share its structural and functional properties with the ligand-gated ion channels or "Cys-loop" family, which include glycine (Gly), acetylcholine (ACh), and serotonin $\left(5-\mathrm{HT}_{3}\right)$ receptors ${ }^{7}$. The complexity of $\mathrm{GABA}_{\mathrm{A}}$ receptors lies in the number of subunits they contain, and in the different combinations in which they are assembled. There are also variants generated by splicing or RNA editing ${ }^{8}$. To date, six subunits have been characterized in humans: six type $\alpha$, three type $\beta$, three type $\gamma$, and one each of type $\delta, \varepsilon, \pi$, and $\theta$, giving this receptor a high degree of heterogeneity. On the other 


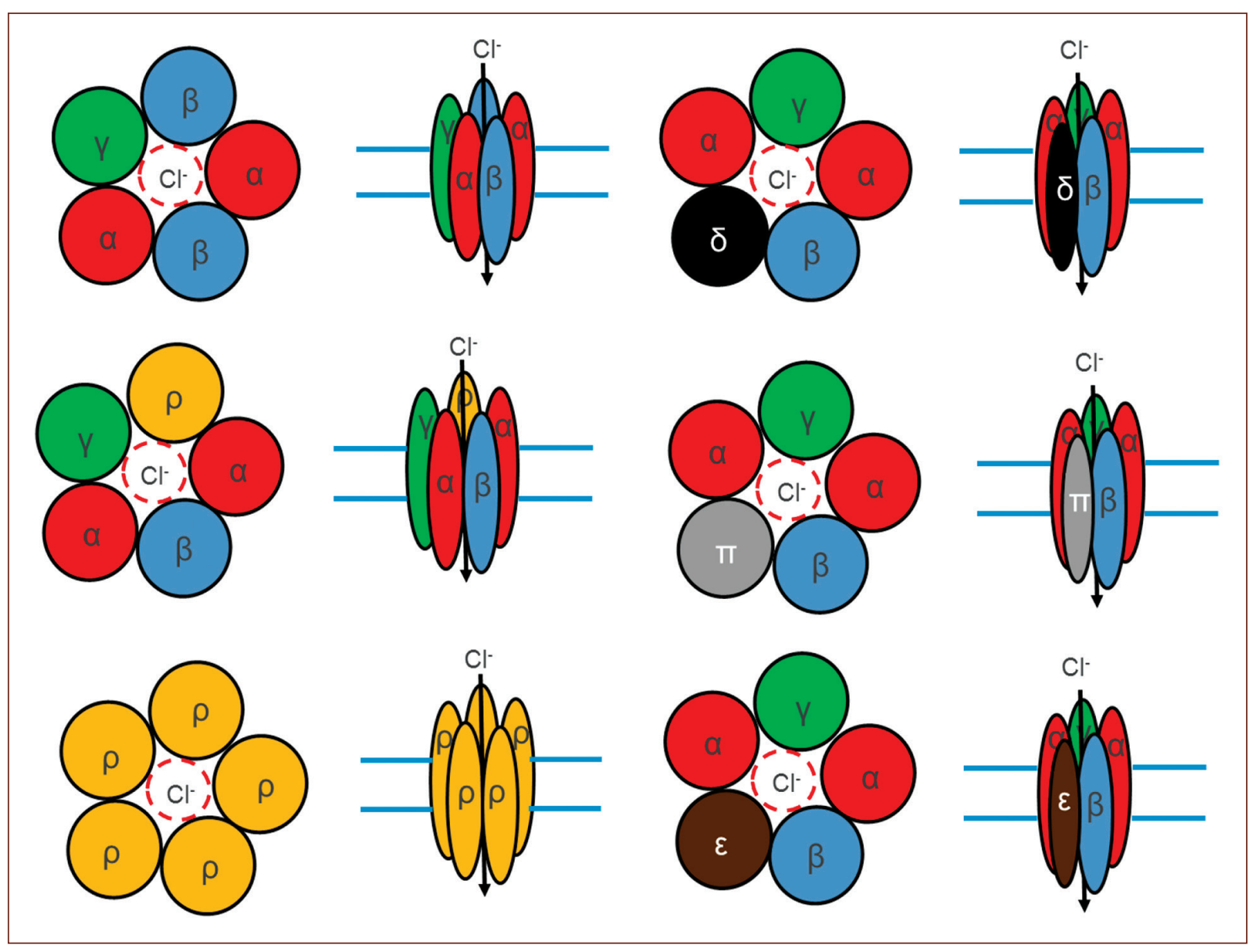

Figure 2. Structural conformation of $\mathrm{GABA}_{\mathrm{A}}$ receptors. Note the number of subunits that contain, and in the different combinations in which they are assembled. Some of them are variants from splicing. giving this receptor a high degree of heterogeneity. On the other hand, three subunits $\rho$ have been characterized, which unlike the others form functional homopentamers. In adult mammals, the most abundant receptor conformation, composed of the subunits $\alpha_{1} \beta_{2} \gamma_{2}$. However, the number of $\mathrm{GABA}_{\mathrm{A}}$ receptor isoforms expressed in mammals is still unknown.

hand, three subunits $\rho$ have been characterized, which unlike the others form functional homopentamers with different pharmacological properties. These subunits are considered a subfamily called $\mathrm{GABA}_{\mathrm{C}}$. In adult mammals, the most abundant isoform is composed of the subunits $\alpha_{1} \beta_{2} \gamma_{2}$. However, the number of $\mathrm{GABA}_{\mathrm{A}}$ receptor isoforms expressed in mammals is still unknown $^{9}$ (Fig. 2).

$\mathrm{GABA}_{\mathrm{A}}$ receptors are selectively blocked by bicuculline and picrotoxin, and they are allosterically modulated by neurosteroids, barbiturates, and benzodiazepines. At present, there is a continuously increasing large number of regulatory molecules for this type of receptors, due to their pathological importance ${ }^{10}$. In the case of $\mathrm{GABA}_{C}$ receptors, they are not regulated by modulators and blockers of the $\mathrm{GABA}_{A}$ receptor. However, they are sensitive to picrotoxin and
1,2,5,6-Tetrahydropyridin-4-yl)methyl phosphonic acid or TPMPA, and specific GABA $_{C}$ antagonist ${ }^{11}$ (Fig. 3). $G_{A B A}$ receptors activation leads to the inhibition of synaptic transmission, due to hyperpolarization in response to a $\mathrm{Cl}^{-}$influx through these receptors ${ }^{12}$. Interestingly, during development there is a delay in the expression of $\mathrm{Cl}^{-}$mobilization systems, generating a high intracellular concentration of this anion ${ }^{13}$. Therefore, an increase of $\mathrm{Cl}^{-}$conductance in response to the activation of $\mathrm{GABA}_{A}$ receptors generates a $\mathrm{Cl}^{-}$outflux current and consequently, cell depolarization, so GABA acts as an excitatory AA during CNS development ${ }^{14}$.

$G_{A B A}$ receptors, or metabotropic, belong to the family of G-protein-coupled receptors or GPCRs, which activate slow responses through the second messengers $^{15}$, and have a limited structural diversity, unlike $\mathrm{GABA}_{\mathrm{A}}$ receptors or metabotropic glutamate receptors 


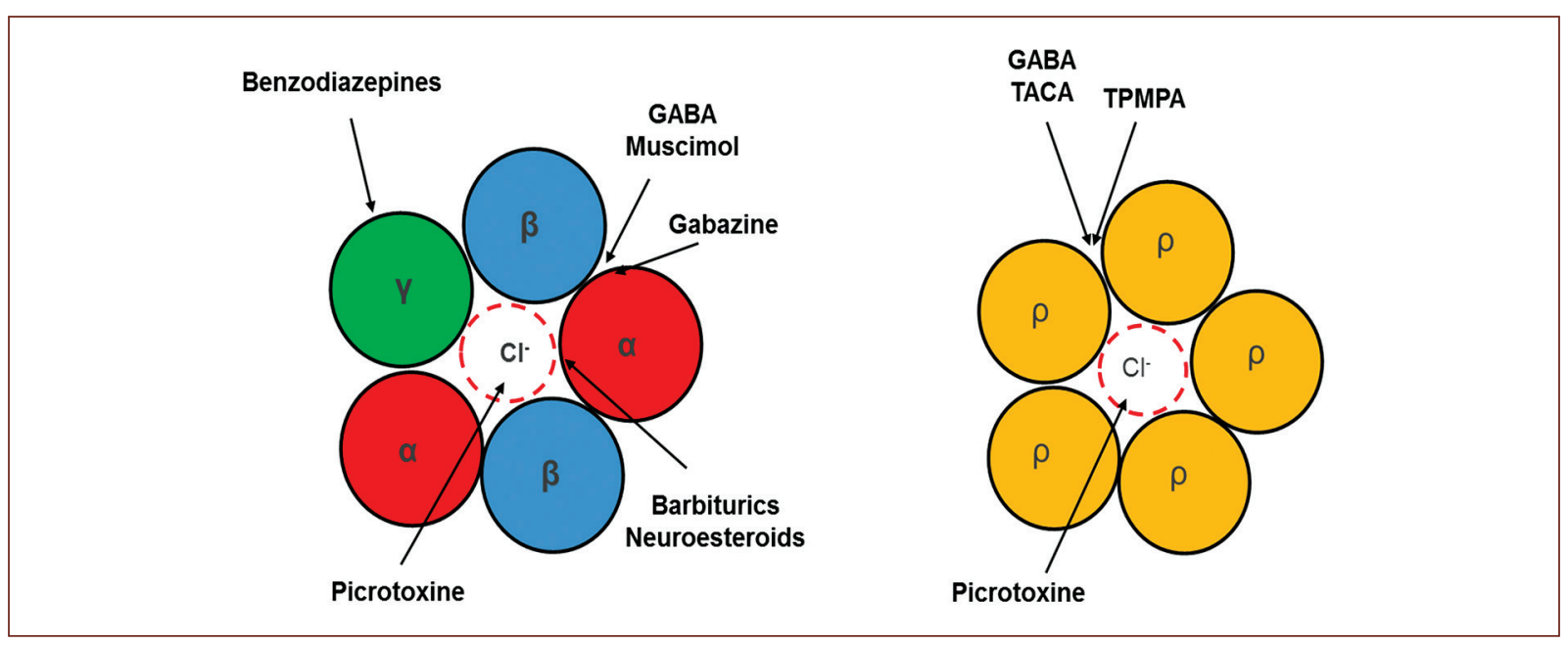

Figure 3. Pharmacology properties of $\mathrm{GABA}_{A}$ receptors. At the right is the classical conformation of the $G A B A_{A}$ receptor, observe the modulation sites were several drugs neuromodulator act to modulate the GABA physiology. These drugs exert their action in different sites of the receptor. Benzodiazepines in the $\gamma$ subunit; Picrotoxin actin the pore of the channel and blocked; the Barbiturics and neurosteroids in the $\alpha$ subunit and, Muscimol and GABAzine compete for the GABA binding site located between $\alpha$ and $\beta$ subunit. On the left side, are functional homopentameric receptor formed by $\rho$. In this case, Picrotixine, as the $\alpha_{1} \beta_{2} \gamma_{2}$ conformation, acts in the pore of the receptors, however, TACA and TPMA compete for the GABA binding site.

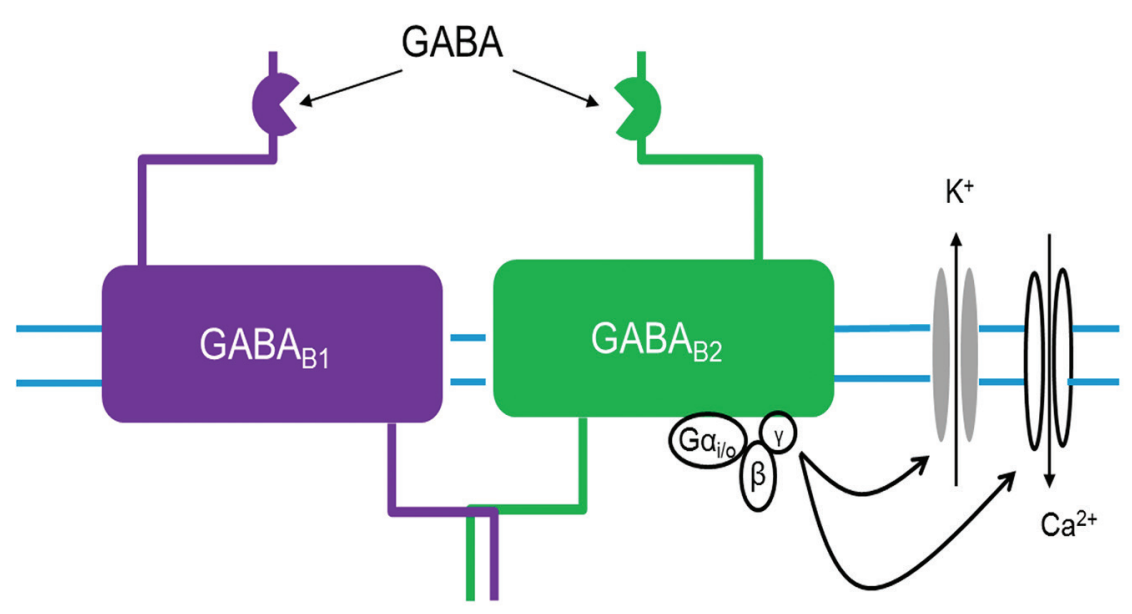

Figure 4. Structural conformation of $\mathrm{GABA}_{B}$ receptor. This receptor is heterodimers composed of the $\mathrm{GABA}_{\mathrm{B} 1}$ or $\mathrm{GABA}_{\mathrm{B} 1}$, belong to the $\mathrm{G}$-protein-coupled receptors, which activate slow responses through the second messengers, that regulate $\mathrm{K}^{+}$and $\mathrm{Ca}^{2+}$ channels. Nevertheless, despite their poor structural diversity, native GABA ${ }_{B}$ receptors show a varied kinetic and pharmacological response.

(mGluRs). $G A B A_{B}$ receptors are heterodimers composed of the $\mathrm{GABA}_{\mathrm{B} 1 \mathrm{a}}$ or $\mathrm{GABA}_{\mathrm{B} 1 \mathrm{~b}}$ subunits combined with the $\mathrm{GABA}_{\mathrm{B} 2}$ subunit. Nevertheless, despite their poor structural diversity, native $\mathrm{GABA}_{B}$ receptors show a varied kinetic and pharmacological response (Fig. 4).

The location of $\mathrm{GABA}_{\mathrm{B}}$ receptors in the synaptic region is key to regulating neurotransmission. Depending on whether the receptor is presynaptic or postsynaptic, their activation generates an inhibition or disinhibition of synaptic activity. At the post-synaptic level, receptor activation induces a $\mathrm{K}^{+}$conductance increase, which is responsible for the "slow" inhibitory events of GABA in the $\mathrm{CNS}^{16}$. The activation of this $\mathrm{K}^{+}$conductance, coupled with negative regulation of $\mathrm{Ca}^{2+}$ influx at the presynaptic 


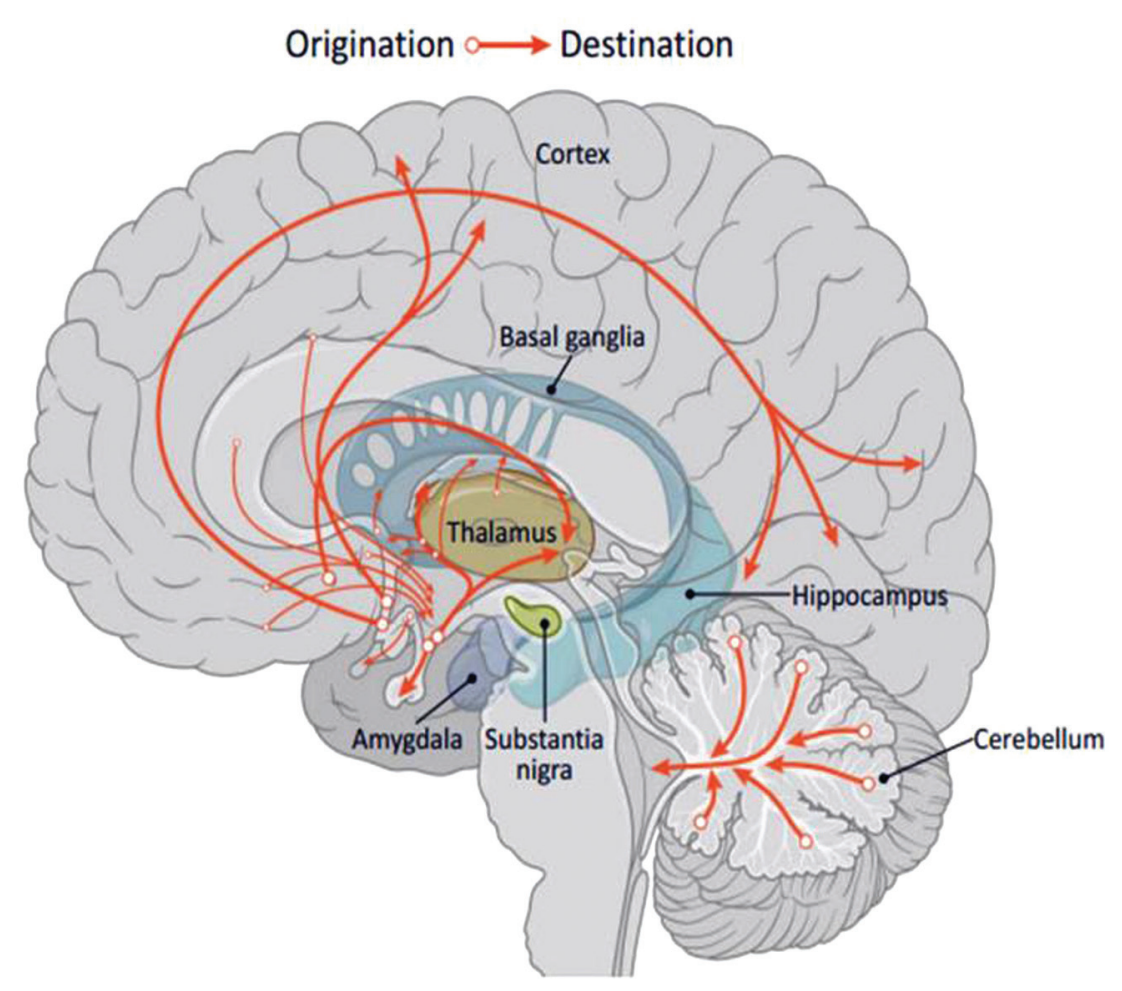

Figure 5. GABA pathways in the brain. The GABAergic system goes throughout the amygdala, hippocampus, hypothalamus, prefrontal cortex, olfactory bulb, including the spinal cord and even the retina. This wide expression of the GABAergic cells indicates the key role of this inhibitory neurotransmitter in functions in the CNS, such as behavior, motor control, mood, sleep, among others. Modified from Brain Chat. https:// thebrainchat.com/photos/ gamma-aminobutyric-acid-gaba-is-a-naturally-occurring-amino-acid-that-works-as-a/1243388282530289/.

level, decreases the release of GABA by regulating the inhibitory effect mediated by this neurotransmitter ${ }^{17}$.

\section{GABA and the CNS}

The proper functioning of the CNS depends on the balance between the excitatory and inhibitory neurotransmitter systems. The excitatory system is regulated by glutamate, while the inhibitor system is regulated by GABA through interneurons, which modulate the excitatory level generated by glutamate release. These interneurons control the flow of information and the synchronization of the cerebral cortex, despite the existence of a 1:5 proportion with glutamatergic neurons. Suggesting, that the numerical balance between neurons and interneurons determines brain functionality, in the case of the cerebral cortex, the proportion 1:5 indicates that this region is mainly excitatory.

Studies in animal models indicate the presence of GABAergic neurons in regions such as the amygdala, hippocampus, hypothalamus, prefrontal cortex, olfactory bulb, retina, and spinal cord, this observation was corroborated also in human studies. This wide expression of the GABAergic cells indicates that this inhibitory neurotransmitter is involved in many functions in the CNS (Fig. 5), for instance, the thalamocortical pathway, which regulates primordial functions such as behavior, motor control, mood, sleep, and among others.

The thalamocortical pathway consists of GABAergic neurons that project from the thalamic reticular nucleus (nRT) toward the ventral basalis (VB), generating an inhibitory "loop" for a self-modulation of the nRT. GABAergic neurons of the $\mathrm{nRT}$ receive the glutamatergic stimulation from the VB and the cortico-thalamic fibers that are projected from the layer six of the cerebral cortex. In this "loop context," GABA A $_{\mathrm{A}}$ receptors are in glutamatergic thalamocortical and cortico-thalamic neurons, as well as in the GABAergic neurons themselves ${ }^{18}$.

Thanks to benzodiazepines it has been understood the functional differences between the $G_{A B A}$ 
receptors located in the $\mathrm{nRT}$ and the thalamic relay neurons. Since benzodiazepines increase the neurotransmission regulated by $\mathrm{GABA}_{\mathrm{A}}$ receptors, these compounds exacerbate absence seizures; however, they show some therapeutic efficacy in clinical and animal models. This double function of benzodiazepines is because they increase the inhibition regulated by $\mathrm{GABA}_{\mathrm{A}}$ receptors in the $\mathrm{nRT}$, causing a decrease in the inhibitory stimulus of the $\mathrm{nRT}$ toward the thalamic relay neurons ${ }^{19}$. Experimental evidence indicates the participation of $\mathrm{GABA}_{B}$ receptors in the pathogenesis of absence seizures ${ }^{20}$. GABA $A_{B}$ receptors regulate $\mathrm{K}^{+}$, activating low-threshold $\mathrm{Ca}^{2+}$ potentials and consequently, burst firing, and the oscillatory behavior of thalamic neurons. Agonists of these receptors exacerbate absence seizures in animal models in a greater proportion than $\mathrm{GABA}_{\mathrm{A}}$ receptors.

\section{Disorders associated with GABA receptors}

\section{Sleep disorders}

GABA has important involvement in sleep cycle regulation, and for decades benzodiazepines and gaboxadol (alternative to benzodiazepines) have been prescribed for the treatment of insomnia with certain tolerance; however, these compounds have side effects such as addiction, hallucinations, and disorientation. Several alterations in the thalamocortical pathway are associated with sleep problems, a common symptom in different neurological pathologies, and where it has been described an increase in GABA levels and an altered function of GABAergic receptors that contain the $\delta$ subunit $\left(\delta-G A B A_{A}\right)^{21}$.

\section{Epilepsy}

It is known that the mechanisms regulated by the GABA $_{A}$ receptor participate in the partial or generalized generation of tonic-clonic seizures. Pharmacological and gene expression studies suggest a role in the prevention of seizures by blocking the regulation of $\mathrm{GABA}_{\mathrm{A}}$ receptors with specific antagonists. Studies point to changes or differences in the expression of subunits of $\mathrm{GABA}_{\mathrm{A}}$ receptors that correlate with epileptogenesis ${ }^{22}$. There is a relationship between mutations in the $\gamma 2$ subunit and epilepsy in humans ${ }^{23}$, similarly, mutations in the gene encoding the $\delta$ subunit have been associated with some forms of congenital epilepsy in humans ${ }^{24}$.
The regulation system through the $\mathrm{GABA}_{B}$ receptor participates in the prevention of tonic seizures. In humans, an upregulation of the $m R N A$ of the $G A B A_{B} R 1$ subunit in the CA1 region, dentate gyrus, and hilus region of the hippocampus has been determined in samples of patients with temporal lobe epilepsy ${ }^{25}$. A report indicates an increase in antagonist sites per neuron in the CA3 and the hilus regions of the hippocampus in patients with temporal lobe epilepsy ${ }^{26}$. On the other hand, it was determined that a GABA $A_{B}$ R1 polymorphism (G1465A) confers a high susceptibility to temporal lobe epilepsy and increases the severity of the condition ${ }^{27}$. GABA R1 knockout mice show several seizures per day, as well as depression-like behavior ${ }^{28}$.

\section{Anxiety disorders}

GABA receptors are of great interest for the treatment of anxiety disorders, due to the therapeutic use of benzodiazepines for these conditions. Tests with positron emission tomography and single-photon emission tomography in patients with panic attacks showed an alteration in benzodiazepine binding sites in different areas of the brain $^{29}$. Family studies indicate an association between inhibition of behavior and anxiety disorders. Smoller et al. found an association between an intronic polymorphism in the GAD65 gene with anxiety disorders ${ }^{30}$.

\section{Schizophrenia}

There are numerous hypotheses about the pathophysiology of schizophrenia, one of which proposes an alteration of GABA-regulated neurotransmission ${ }^{31}$. Changes in the expression of genes related to the different subunits that form GABA receptors have been observed $^{32}$. However, this is not specific for GABA, since there are also changes in gene expression of other neurotransmitters. Another evidence that supports the GABA hypothesis in schizophrenia is that the treatment of this pathology with antiepileptic drugs shows positive clinical results in schizophrenic patients ${ }^{33,34}$. The use of benzodiazepines in combination with antiepileptic drugs reduces considerably the symptoms of schizophrenia and anxiety. On the other hand, the administration of valproate with neuroleptics controls efficiently irritability symptoms and violent behaviors.

The genes that encode $G_{A B A} R 1$ are located within the loci of schizophrenia, suggesting the participation of this receptor in this disorder ${ }^{35}$. These observations suggest that the $G A B A_{B} R 1$ receptor may be a pharmacological target for schizophrenia. 


\section{Depression}

In recent years, different reports showed evidence about the association between GABA and depression. For example, a decrease of this neurotransmitter in the cerebrospinal fluid of patients with depression has been reported ${ }^{36}$. Magnetic resonance spectroscopy in depressive patients showed a reduction in GABA levels, mainly in the occipital cortex (OCC) and in some areas of the prefrontal cortex (PFC) ${ }^{37}$. Studies indicate changes in the regulation of the genes which encoding GABA receptors. For example, Choudary and col. showed the deregulation of the $\beta_{3}, \gamma_{2}$, and $\delta$ subunits in the frontal cortex ${ }^{38}$. In this regard, the postmortem analysis by PCR of different brain regions from suicide victims with depression showed alterations in the $\alpha_{5}$, $\gamma_{1}$, and $\gamma_{2}$ subunits of the dorsolateral and lateral inferior $\mathrm{PFC}^{39}$. Fatemi and col. found an increase in the $\alpha_{2}, \alpha_{2}$, $\gamma_{3}$, and $\varepsilon$ subunits in the cerebellum of non-suicidal patients with depression ${ }^{40}$.

\section{Premenstrual dysphoric disorder (PMDD)}

Changes in cognition, mood, and sensitivity to medications throughout the premenstrual cycle have been attributed to hormonal regulation of GABAergic transmission ${ }^{41}$. PMDD occurs during the luteal phase of the menstrual cycle and is characterized by significant alterations in behavior, mood, and a physical limitation that compromises personal, social, and professional development. In healthy women, plasmatic levels of GABA increase from the follicular to the luteal phase, while they decrease in women suffering from PMDD ${ }^{42}$. However, in the CNS, GABA levels increase in this same phase ${ }^{43}$. An increase in cortical inhibitory activity has been reported in healthy women, whereas this effect is not observed in women with $\mathrm{PMDD}^{44}$. Deregulation of GABA levels possibly is secondary to the action of allopregnanolone, a metabolite of progesterone secreted during the luteal phase. This hormone acts on $\mathrm{GABA}_{\mathrm{A}}$ receptors that contain the $\alpha_{4}$ and $\delta$ subunits ${ }^{45}$. During periods of fluctuation of progesterone concentrations, there are changes in the expression of the $\alpha_{4}$ and $\delta$ subunits in the CA1 region of the hippocampus. Furthermore, a decrease in the $\alpha_{1}$ subunit has been observed ${ }^{42}$.

\section{Alcoholism}

It is well known that the main ethanol target in the CNS is the GABA $_{A}$ receptors ${ }^{46}$, for example, studies in rodents show that the systemic administration of GABA receptors agonists or antagonists modulates the ethanol consumption ${ }^{47}$. GABA $A$ receptors increase their probability of aperture and/or their affinity for the agonist after an acute ethanol intake. They are generally potentiated by low concentrations of ethanol (5-50 mM) that correspond to very low intake in humans (a couple of drinks). Chronic exposure to ethanol generates different specific neuroadaptations in GABAergic synapses in different regions of the brain. Furthermore, chronic exposure to ethanol alters the expression of different subunits of $\mathrm{GABA}_{A}$ receptors at the transcriptional level in different regions of the brain involved in the development of alcohol dependence. For example, in the cerebral cortex, chronic exposure to ethanol decreases mRNA and the expression of $\alpha 1, \alpha 2$, and $\alpha 3$ subunits, and increases the expression of $\alpha 4, \beta 1, \beta 2$, $\beta 3, \gamma 1$, and $\gamma 2$ subunits $^{48}$. In humans, sequencing assays have identified different genes encoding $G_{A B A}$ receptors associated with alcohol consumption, such as $\alpha 3$ (GABRA3) in the prefrontal cortex, $\gamma 1$ (GABRG1), and $\gamma 2$ (GABRG2) in the hippocampus ${ }^{49}$. These expression changes probably alter the assembly of $\mathrm{GABA}_{\mathrm{A}}$ receptors, modifying their binding affinity to the ligand and, consequently, their function. In the case of the hippocampus, alterations in the expression of $\mathrm{GABA}_{\mathrm{A}}$ receptors depend on the time of exposure to ethanol. A 40-day chronic exposure significantly increased the levels of the $\alpha 4$ subunit; however, no alterations were observed in the $\alpha 1, \alpha 2, \alpha 3, \beta(2 / 3)$, or $\gamma 2$ subunits $^{50}$. These results indicate a regulation in the expression of subunits of $\mathrm{GABA}_{A}$ receptors specific to each region of the brain that is dependent on the length of exposure to ethanol.

In the case of $\mathrm{GABA}_{\mathrm{B}}$ receptors, they are determinants of the specificity of ethanol effects on certain regions of the brain. For example, Peris and col. showed that chronic ethanol treatment increases the release of GABA, decreasing long-term potentiation ${ }^{51}$. Exposure to baclofen ( $G A B A_{B}$ antagonist) decreases this release of GABA, whereas 2-OH-saclofen $\left(\mathrm{GABA}_{B}\right.$ antagonist) enhances it. This chronic effect of ethanol on the release of GABA into the synaptic cleft could explain the reduction in long-term potentiation observed after chronic exposure to ethanol.

\section{Conclusion}

Its complex structural diversity, associated with its differential expression pattern in the neural loops of the brain, makes it very difficult to understand its inhibitory 


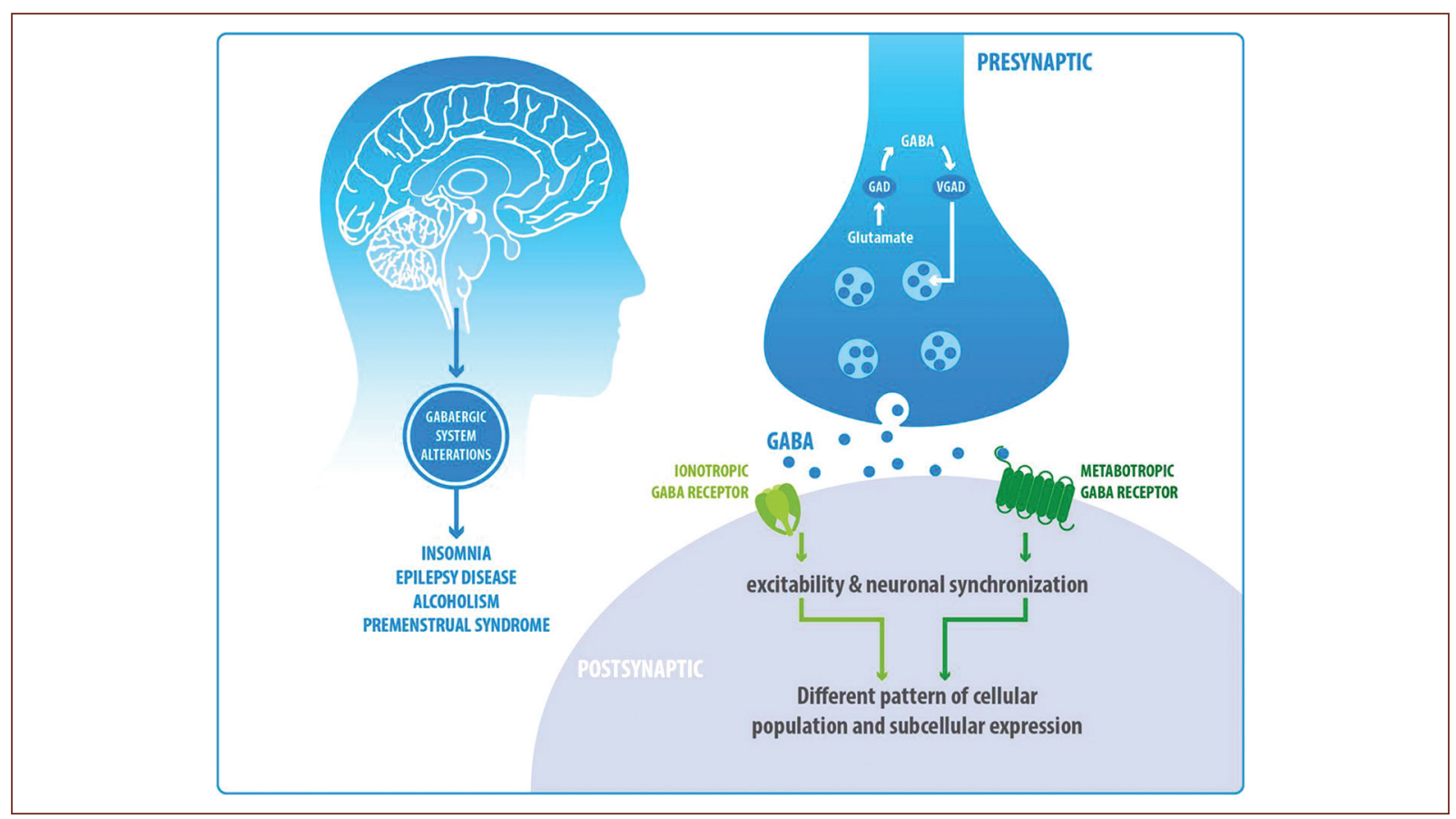

Figure 6. Its complex structural diversity, associated with its differential expression pattern in the neural loops of the brain, makes it very difficult to understand its inhibitory control in different neural networks. Although our knowledge about the specific functions of GABAergic receptors in a neural loop is limited, there is evidence that suggests that the same subtype of GABAergic receptors can be expressed in different neuronal populations with different subcellular locations and in different areas of the brain, modulating the excitability and neuronal synchronization in different ways (Fig. 6). Therefore, understanding the role that GABA plays in the brain is possible only through the specific study of a receptor subtype, a loop, or a neuronal type, considering important variables such as previous synaptic physiology, synaptic activity, sex, or the circadian cycle, are partially explored along with GABA.

control in different neural networks. Although our knowledge about the specific functions of GABAergic receptors in a neural loop is limited, there is evidence that suggests that the same subtype of GABAergic receptors can be expressed in different neuronal populations with different subcellular locations and in different areas of the brain, modulating the excitability and neuronal synchronization in different ways (Fig. 6). Therefore, understanding the role that GABA plays in the brain is possible only through the specific study of a receptor subtype, considering important variables such as synaptic activity, sex, or the circadian cycle, are partially explored along with GABA.

\section{Funding}

This article was supported by grants from PAPIIT-UNAM IA205918 and IN221820 and sponsorship by Departamento de Bioquímica, Facultad de Medicina, UNAM and Asociación para Evitar la Ceguera en México I.A.P Hospital Dr Luis Sánchez Bulnes.

\section{Conflicts of interest}

The authors declare that they have not conflicts of interest.

\section{Ethical disclosures}

Protection of human and animal subjects. The authors declare that no experiments were performed on humans or animals for this study.

Confidentiality of data. The authors declare no patients data appear in this article.

Right to privacy and informed consent. The author declares that no patient data appear in this article.

\section{References}

1. Scot R, Leonard $S$. New functions for amino acids: effects on gene transcription and translation. Am J Clin Nut. 2006;83:500-7.

2. Krnjevíc K, Phillis JW. Iontophoretic studies of neurons in the mammalian cerebral cortex. J Physiol. 1963;165:274-304.

3. Soghomonian JJ, Martin DL. Two isoforms of glutamate decarboxylase: why? Trends Pharmacol Sci. 1998;19:500-5. 
4. Erlander MG, Tillakaratne NJ, Feldblum S, Patel N, Tobin AJ. Two genes encode distinct glutamate decarboxylases. Neuron. 1991;7:91-100.

5. Langendorf CG, Tuck KL, Key TL, Fenalti G, Pike RN, Rosado CJ, et al Structural characterization of the mechanism through which human glutamic acid decarboxylase auto-activates. Biosci Rep. 2013;33:137-44.

6. Pinal CS, Tobin AJ. Uniqueness and redundancy in GABA production Perspect Dev Neurobiol. 1998;5:109-18.

7. Keramidas A, Moorhouse AJ, Schofield PR, Barry PH. Ligand-gated ion channels: mechanisms underlying ion selectivity. Prog Biophys Mol Biol. 2004;86:161-204

8. Daniel C, Ohman M. RNA editing and its impact on GABAA receptor function. Biochem Soc Trans. 2009;37:1399-403.

9. Whiting PJ. GABA-a receptor subtypes in the brain: a paradigm for CNS drug discovery? Drug Discov Today. 2003;8:445-50.

10. Johnston GA. Unsaturated analogues of the neurotransmitter GABA trans-4-aminocrotonic, cis-4-aminocrotonic, and 4-aminotetrolic acids Neurochem Res. 2016;41:476-80.

11. Olsen RW, Sieghart W. GABA a receptors: subtypes provide diversity of function and pharmacology. Neuropharmacology. 2009;56:141-8.

12. Mody I. Aspects of the homeostatic plasticity of GABAA receptor-mediated inhibition. J Physiol. 2005;1:37-46.

13. Zhang L, Spigelman I, Carlen PL. Development of GABA-mediated, chloride-dependent inhibition in CA1 pyramidal neurons of immature rat hippocampal slices. J Physiol 1991;444:25-49.

14. Ben-Ari Y. Excitatory actions of GABA during development: the nature of the nurture. Nat Rev Neurosci. 2002;3:728-39.

15. Ulrich $D$, Bettler B. GABA(B) receptors: synaptic functions and mechanisms of diversity. Curr Opin Neurobiol. 2007;17:298-303.

16. Otis TS, De Koninck Y, Mody I. Characterization of synaptically elicited GABAB responses using patch-clamp recordings in rat hippocampal slices. J Physiol. 1993;463:391-407.

17. Thompson SM, Gähwiler BH. Comparison of the actions of baclofen at pre-and postsynaptic receptors in the rat hippocampus in vitro. J Physiol. 1992;451:329-45.

18. McCormick DA, Bal T. Sleep, and arousal: thalamocortical mechanisms. Annu Rev Neurosci. 1997;20:185-215.

19. Huguanard JR, Prince DA. Clonazepam suppresses GABAB mediated inhibition in thalamic relay neurons through effects in nucleus reticularis. J Neurophysiol. 1994;71:2576-81.

20. Crunelli V, Leresche N. Childhood absence epilepsy: genes, channels, neurons, and networks. Nat Rev Neurosci. 2002;3:371-82.

21. Wafford KA, Van-Niel MB, Ma QP, Horridge E, Herd MB, Peden DR et al. Novel compounds selectively enhance delta subunit-containing GABA A receptors and increase tonic currents in the thalamus. Neuropharmacology. 2009;56:182-9.

22. Loup F, Wieser HG, Yonekawa Y, Aguzzi A, Fritschy JM. Selective alterations in GABAA receptor subtypes in human temporal lobe epilepsy. $J$ Neurosci. 2000;20:5401-19.

23. Baulic S, Huberfeld G, Gourfinkel-An I, Mitropoulou G, Beranger A Prud'homme JF, et al. First genetic evidence of GABAA receptor dysfunction in epilepsy: a mutation in the 2-subunit gene. Nat Genet. 2001 28:46-8.

24. Mulley JC, Scheffer IE, Harkin LA, Berkovic SF, Dibbens LM. Susceptibility genes for complex epilepsy. Hum Mol Genet. 2005;14:R243-9.

25. Billington A, Baird VH, Thom M, Duncan JS, Upton N, Bowery NG GABAB (1) mRNA expression in hippocampal sclerosis associated with human temporal lobe epilepsy. Mol Brain Res. 2001;86:84-9.

26. Princivalle AP, Duncan JS, Thom M, Bowery NG. Studies of GABAB receptors labeled with [3H]-CGP62349 in hippocampus resected from patients with temporal lobe epilepsy. Br J Pharmacol. 2002;136:1099-106.

27. Gambardella A, Manna I, Labate A, Chifari R, La-Russa A, Serra P, et al. GABA (B) receptor 1 polymorphism (G1465A) is associated with temporal lobe epilepsy. Neurology. 2003;60:560-3.

28. Schuler V, Luscher C, Blanchet C, Klix N, Sansig G, Klebs K, et al. Epilepsy, hyperalgesia, impaired memory, and loss of pre-and postsynaptic GABAB responses in mice lacking GABAB (1). Neuron. 2001;31:47-58.

29. Hasler G, Nugent AC, Carlson PJ, Carson RE, Geraci M, Drevets WC Altered cerebral gamma-aminobutyric acid type a-benzodiazepine receptor binding in panic disorder determined by [11C]flumazenil positron emission tomography. Arch Gen Psychiatry. 2008;65:1166-75.
30. Smoller JW, Rosenbaum JF, Biederman J, Susswein LS, Kennedy J, Kagan J, et al. Genetic association analysis of behavioral inhibition using candidate loci from mouse models. Am J Med Genet. 2001;105:226-35.

31. Benes FM, Berreta S. GABAergic interneurons: implications for understanding schizophrenia and bipolar disorder. Neuropsychopharmacology. 2001;25:1-27.

32. Akbarian S, Huntsman MM, Kim JJ, Tafazzoli A, Potkin SG, Bunney WE, et al. GABAA receptor subunit expression in human prefrontal cortex: comparison of schizophrenics and controls. Cereb Cortex. 1995;5:550-60.

33. Hosak L, Libiger J. Antiepileptic drugs in schizophrenia. Eur Psychiatry. 2002:17:371-8.

34. Sander T, Peter C, Kammer G, Samochowiec J, Zirra M, Mischke D, et al. Association analysis of exonic variants of the gene encoding GABAB receptor and idiopathic generalized epilepsy. Am J Med Genet. 1999;88:305-10.

35. Fatemi SH, Folsom TD, Thuras PD. GABA A and GABA B receptor dysregulation in superior frontal cortex of subjects with schizophrenia and bipolar disorder. Synapse. 2017;71:21973.

36. Gold $\mathrm{BI}$, Bowers MB Jr. Roth $\mathrm{RH}$, Sweeney DW. GABA levels in CSF of patients with psychiatric disorders. Am J Psychiatry. 1980;137:362-4.

37. Hasler G, van der Veen JW, Tumonis T, Meyers N, Shen J, Drevets WC. Reduced prefrontal glutamate/glutamine and gamma-aminobutyric acid levels in major depression determined using proton magnetic resonance spectroscopy. Arch Gen Psychiatry. 2007;64:193-200.

38. Choudary PV, Molnar M, Evans SJ, Tomita H, Li JZ, Vawter MP, et al. Altered cortical glutamatergic and GABAergic signal transmission with glial involvement in depression. Proc Natl Acad Sci U S A. 2005;102:15653-8.

39. Sequeira A, Mamdani F, Ernst C, Vawter MP, Bunney WE, Lebel V, et al. Global brain gene expression analysis links glutamatergic and GABAergic alterations to suicide and major depression. PLoS One. 2009;4:e6585.

40. Fatemi SH, Folsom TD, Rooney RJ, Thuras PD. Expression of GABAA $\alpha 2-, \beta 1-$ and $\varepsilon$-receptors are altered significantly in the lateral cerebellum of subjects with schizophrenia, major depression, and bipolar disorder. Transl Psychiatry. 2013;3:e303.

41. Sundström I, Andersson A, Nyberg S, Ashbrook D, Purdy R, Bäckström T. Patients with premenstrual syndrome have a different sensitivity to neuroactive steroid during the menstrual cycle compared to control subjects. Neuroendocrinology. 1998;67:126-38.

42. Smith SS, Shen H, Gong QH, Zhou X. Neurosteroid regulation of GA$\mathrm{BA}(\mathrm{A})$ receptors: focus on the alpha4 and delta subunits. Pharmacol Ther. 2007;116:58-76

43. Epperson CN, Haga K, Mason GF, Sellers E, Gueorguieva R, Zhang W, et al. Cortical $\gamma$-aminobutyric acid levels across the menstrual cycle in healthy women and those with premenstrual dysphoric disorder. Arch Gen Psychiatry. 2002;59:851-8.

44. Smith MJ, Greenberg BD, Adams LF, Nguyen M, Schmidt PJ, Rubinow DR, et al. Menstrual-related changes in cortical excitability in women with PMS and controls. Biol Psychiatry. 2000;47:69S.

45. Shen H, Gong QH, Aoki C, Yuan M, Ruderman Y, Dattilo M, et al. Reversal of neurosteroid effects at alpha4beta2delta GABAA receptors triggers anxiety at puberty. Nat Neurosci. 2007;10:469-77.

46. Koob GF. Alcoholism: allostasis and beyond. Alcohol Clin Exp Res. 2003;27:232-43

47. Boyle AE, Segal R, Smith BR, Amit Z. Bidirectional effects of GABAergic agonists and antagonists on the maintenance of voluntary ethanol intake in rats. Pharmacol Biochem Behav. 1993;46:179-82.

48. Devaud LL, Smith FD, Grayson DR, Morrow AL. Chronic ethanol consumption differentially alters the expression of gamma-aminobutyric acid a receptor subunit mRNAs in rat cerebral cortex: competitive, quantitative reverse transcriptase-polymerase chain reaction analysis. Mol Pharmacol. 1995:48:861-8.

49. Zhou Z, Yuan Q, Mash DC, Goldman D. Substance-specific and shared transcription and epigenetic changes in the human hippocampus chronically exposed to cocaine and alcohol. Proc Natl Acad Sci U S A. 2011;108:6626-31.

50. Matthews DB, Devaud LL, Fritschy JM, Sieghart W, Morrow AL. Differential regulation of GABA $(A)$ receptor gene expression by ethanol in the rat hippocampus versus cerebral cortex. J Neurochem. 1998;70:1160-6.

51. Peris J, Eppler B, Hu M, Walker DW, Hunter BE, Mason K, et al. Effects of chronic ethanol exposure on GABA receptors and GABAB receptor modulation of $3 \mathrm{H}-\mathrm{GABA}$ release in the hippocampus. Alcohol Clin Exp Res. 1997;21:1047-52. 